\title{
Sustainable and regional gastronomy: cassava leaves as a potential ingredient for gluten-free biscuits
}

\section{Gastronomia regional e sustentável: follhas de mandioca como potencial ingrediente para biscoitos} sem glúten

Gastronomía regional y sustentable: hojas de yuca como ingrediente potencial para galletas sin glúten

Elisa Cristina Andrade Neves ORCID: https://orcid.org/0000-0001-5849-9244 University of Campinas, Brazil Federal University of Pará, Brazil E-mail: eneves@ufpa.br

Beatriz Andrade Moysés ORCID: https://orcid.org/0000-0002-2694-7396 University of Campinas, Brazil.

E-mail: andradebiam@gmail.com Daniela Andrade Neves ORCID: https://orcid.org/0000-0001-8007-8382 University of Campinas, Brazil E-mail: dani_ela_neves@yahoo.com.br

Pedro Henrique Campelo

ORCID: https://orcid.org/0000-0002-4048-3858 Federal University of Amazonas, Brazil

E-mail: pedrocampelo@ufam.edu.br

Maria Teresa Pedrosa Silva Clerici ORCID: https://orcid.org/0000-0002-8445-336X University of Campinas, Brazil E-mail: mclerici@unicamp.br

\begin{abstract}
The addition of roots derivatives to bakery products may be a promising alternative to add value to these products. This study aimed to characterize and evaluate the effect of cassava leaves on the properties of gluten-free biscuits (GFB). The ingredients used were cassava flour, rice flour, cuí, tapioca flour, and 0 (F0), 3.69\% (F1), 5.34\% (F2), and 7.38\% (F3) of cassava leaves (CCL). The results were evaluated by analysis of variance, followed by Scott-Knott test (pvalue $<0.05$ ). The CCL presented $89.9 \%$ moisture, water activity of 0.98 , and $2.75 \%$ protein; tryptophan was the limiting amino acid. No significant differences were observed between the F0-control and those made with the addition of CCL, which presented moisture and Aw below $3 \%$ and 0.30 , and hardness between 45 to $60 \mathrm{~N}$. The sensory acceptance scores were greater than 6 , which indicates that it is possible to increase the added value of CCL in bakery products. The use of cassava leaves in biscuits showed good technological and sensory characteristics, making it possible to be an ingredient from regional by-products that can favor sustainable development, respect the concept of regionalization, and add income and employment.
\end{abstract}

Keywords: Sustainable food; Cassava by-products; Rich-protein leave; Celiac food; Cyanogenic compounds.

\section{Resumo}

A utilização de derivados de raízes em produtos de panificação pode ser uma alternativa promissora para agregar valor a esses produtos. Este trabalho teve como objetivo caracterizar e avaliar o efeito das folhas de mandioca nas propriedades de biscoitos sem glúten (BSG). Os ingredientes utilizados foram farinha de mandioca, farinha de arroz, cuí, farinha de tapioca e 0 (F0), 3,69\% (F1), 5,34\% (F2) e 7,38\% (F3) de folhas de mandioca (CCL). Os resultados foram avaliados pela análise de variância, seguida do teste de Scott-Knott (p-valor <0,05). O CCL apresentou 89,9\% de umidade, 0,98 de atividade de água e 2,75\% de proteína; triptofano era o aminoácido limitante. Não foram observadas diferenças significativas entre o F0-controle e os com adição de CCL, que apresentaram umidade e Aw abaixo de 3\% e 0,30 , respectivamente, e dureza entre 45 a $60 \mathrm{~N}$. Os escores de aceitação foram maiores que 6 , o que indica que é possível aumentar o valor agregado do CCL em produtos de panificação. $\mathrm{O}$ uso de folhas de mandioca em biscoitos apresentou boas características tecnológicas e sensoriais, podendo ser um ingrediente de para elaboração de produtos regionais, que pode favorecer o desenvolvimento sustentável, respeitar o conceito de regionalização e agregar renda e emprego na cadeia produtiva da mandioca. 
Palavras-chave: Sustentabilidade; Produtos de mandioca; Proteínas em folhas; Compostos cianogênicos.

\section{Resumen}

La adición de derivados de raíces a los productos de panadería pueden ser una alternativa prometedora para dar un valor agregado a estos productos. Este estudio tuvo como objetivo caracterizar y evaluar el efecto de las hojas de yuca en las propiedades de galletas sin gluten (GFB). Los ingredientes utilizados fueron harina de yuca, harina de arroz, cuí, harina de tapioca (almidón de yuca), y hojas de yuca (CCL) en $0 \%(\mathrm{~F} 0)$, 3.69\% (F1), 5.34\% (F2) y 7.38\% (F3). Los resultados fueron evaluados por análisis de varianza, seguido de la prueba de Scott-Knott $(\mathrm{p}<0.05)$. Las CCL presentaron $89.9 \%$ de humedad, 0.98 de $\mathrm{a}_{\mathrm{w}}, \mathrm{y} 2.75 \%$ de proteína, con el triptófano como aminoácido limitante. No se observaron diferencias significativas entre las galletas F0-control y las elaboradas con adición de CCL, las cuales presentaron una humedad y $a_{\mathrm{w}}$ por debajo del $3 \%$ y 0.30 , respectivamente, y una dureza entre 45 a $60 \mathrm{~N}$. Los puntajes de la aceptación sensorial fueron mayores a 6 puntos, lo que indica que es posible aumentar el valor agregado de las CCL en productos de panadería. El uso de hojas de yuca en la produjo galletas con buenas características tecnológicas y sensoriales, lo que las convierte en un ingrediente proveniente de subproductos regionales que puede favorecer al desarrollo sostenible, respetando el concepto de regionalización, y generar mayores ingresos y empleo.

Palabras clave: Comida sustentable; Coproductos de la yuca; Hoja rica en proteína; Comida para celíacos; Compuestos cianogénicos.

\section{Introduction}

The COVID-19 pandemic has brought a warning to world economies, especially about the food production chain. In times of crisis, countries tend to close their economies, mainly the food trade, to guarantee the internal supply of their population (Hobbs, 2020; Hoover, 2020). In times of a pandemic is a health risk related to the transport of these supplies. There is a possibility that food, packaging, and other equipment may be contaminated, offering risks to the local population's health (Laborde et al., 2020).

The consumption of gluten free foods is increasing in today's society and consumers are demanding more from their gluten free products (Muggah et al., 2016; Yilmaz \& Koca, 2020). According to Di Cairano et al. (2018) and Valitutti et al. (2017) biscuits and crackers are considered as important sources of carbohydrates and can be used to make nutrients available to celiac individuals. Differently from the gluten-free breads, gluten-free biscuits (GFB) do not require the development of gluten, a three-dimensional network to retain gases, therefore their formulations allow the use of a larger variety of flours (Di Cairano et al., 2018), and however they show that products can have different flavors, colors and regional uses of ingredients. In addition to rice flour proteins, another alternative is the use of cassava leaves as an unconventional source of protein and dietary fiber.

Modesto Junior et al (2019) determined that the protein content in leaves of nine cassava varieties produced in Para, Brazil ranged from 19.73 to $29.47 \mathrm{~g} / 100 \mathrm{~g}$ on a dry basis. Latif and Muller (2015) stated that the cassava leaves have the potential to be used for human consumption.

In Brazil, they are little explored for food purposes, being used only by the population of the northern region in the preparation of typical dishes. Due to the large production of cassava roots in Brazil, the increase in the consumption of leaves may also be an alternative for family farming, thus actions to improve its addition to high value-added products, such as bakery, are necessary, aiming at the intensification of the cassava production.

Besides the use of gluten-free flour from cereals, pseudo cereals and seeds, ingredients extracted from tuberous roots have been used in the production of GFB, such as cassava flour and cassava bran (Rodrigues et al., 2011) and cassava starch (Silva et al., 2015). Therefore, the use of cassava derivatives as a source of carbohydrates has great potential, especially in Brazil, which ranked fourth in the world production of cassava roots in 2017, with a stable production in recent years $(19,000,000$ tons) (FAOSTAT, 2020). Cassava flour also has the potential to be used in the preparation of GFB due to its higher starch levels (greater than 80\%) and higher fiber content when compared to starch (Neves et al., 2017), as well as cuí, the co-product of tapioca flour processing, due to its pre-gelatinized starch content.

This study aimed to enable the use of cassava derivatives and cassava leaves as a protein source in gluten-free biscuits, 
aiming to promote the insertion of these co-products in higher added value formulations.

\section{Methodology}

\subsection{Material}

The ingredients cooked cassava leaves (CCL); white cassava flour (WCF), used as a starchy base ingredient; tapioca flour (TF) and cuí (C), a co-product of tapioca flour processing was purchased from the Ver-o-Peso Market complex (BelémPA, Brazil, geographic coordinates, 01027’21” S; 48o 30' 16” W). The other ingredients were purchased from the local market.

\subsection{Characterization of rice flour and cassava derivatives}

The cooked cassava leaves (CCL), white cassava flour (WCF), tapioca flour (TF), cuí (C), and rice flour (RF) were characterized according to the following methodologies:

- Moisture determined in triplicate according to the Association of Official Analytical Chemists (AOAC, 2005) (method 925.09); - Water activity (Aw) determined in triplicate in the Aqualab apparatus (Aqualab, 4TEV, Decagon, Pullman, USA) using a dew point sensor;

- Color measurements in a CR-10 colorimeter (Konica Minolta, Tokyo, Japan) with D65 illuminant, using three light flashes on the CIE-Lab system;

- Cyanogenic compounds, determined in cassava derivatives according to Oliveira \& Oliveira (2010);

- Paste properties of the starchy ingredients, determined in duplicate in a Rapid Visco-Analyzer (RVA 4500) using the Extrusion software from Thermocline for Windows, version 2.3;

- Starch morphology assessed using an Olympus BX51 polarized light optical microscope with an Olympus E-330 digital camera at $40 \mathrm{X}$ magnification.

The cooked cassava leaves (CCL) were also characterized for:

- Proximate composition, in triplicate, according to AOAC official methods (AOAC, 2005): moisture (method 925.09); proteins (method 920.87); lipids (method 920.85); ash (method 923.03), and total dietary fiber (method 985-29). Digestible carbohydrate contents were calculated by difference [100 - (moisture + protein + lipid + ash + dietary fiber)];

- Amino acid profile according to White et al. (1986) and Hagen et al. (1993), and tryptophan contents according to Lucas and Sotelo (1980); Amino acid scoring pattern, calculated as a ratio of the amount of each essential amino acid (mg/g protein) in a sample and the amount of the respective amino acid in an ideal protein, according to the recommendations of FAO/WHO (1985) for older adults to 18 years.

\subsection{Preparation of gluten-free biscuits}

The gluten-free biscuits (GFB) were elaborated, adapted from Silva et al. (2015), replacing potato starch with cassava flour, considering as a starchy base the white cassava flour (WCF) (Table 1), being the control formulation (F0) and formulations with the addition of $3.69 \%$ (F1), 5.54\% (F2), and $7.38 \%$ (F3) of CCL. 
Table 1. Formulations of gluten-free biscuits control and with the addition of cooked cassava leaves

\begin{tabular}{lllll}
\hline \multicolumn{1}{c}{ Ingredients } & F0 (\%) & F1 (\%) & F2 (\%) & F3 (\%) \\
\hline White cassava flour & 24.39 & 23.60 & 23.60 & 23.60 \\
Vegetable fat & 22.87 & 22.13 & 22.13 & 22.13 \\
Sugar & 20.96 & 20.29 & 20.29 & 20.29 \\
Cuí & 7.62 & 7.38 & 7.38 & 7.38 \\
Rice flour & 6.10 & 5.90 & 5.90 & 5.90 \\
Tapioca flour & 5.72 & 5.53 & 5.53 & 5.53 \\
Cocoa powder & 3.80 & 3.69 & 3.69 & 3.69 \\
Salt & 0.19 & 0.18 & 0.18 & 0.18 \\
Baking powder & 0.13 & 0.12 & 0.12 & 0.12 \\
Spices & & 0.07 & 0.07 & 0.07 \\
Ammonia carbonate & 0.08 & 0.04 & 0.04 & 0.04 \\
Water & 0.04 & 7.38 & 5.53 & 3.69 \\
Cooked cassava leaves & 8.10 & 3.69 & 5.54 & 7.38 \\
\hline
\end{tabular}

${ }^{a}$ Cinnamon powder, cloves powder, and nutmeg powder, in equal parts. Source: Authors.

For the preparation of GFB, the dry ingredients were mixed. Then, fat, water and cooked cassava leaves were added. Tapioca flour was added after a uniform and non-adherent dough was formed. The resulting dough was manually rolled out and cut into a circular shape $(\mathrm{h}=6.5 \mathrm{~mm}$ and $\varnothing=3.5 \mathrm{~cm})$, and the biscuits were baked at $160^{\circ} \mathrm{Cfor} 20$ minutes. The baked GFBs were cooled for 1 hour, vacuum packed in multi-layer laminated packaging, and stored at $20^{\circ} \mathrm{C}$.

\subsection{Characterization of GFB}

\subsubsection{Physicochemical characterization}

Moisture contents, water activity, color, and starch morphology were determined in ten GFB according to Section 2.2.

Hardness (expressed as N) was determined in ten GFB of each formulation using TA-XT Plus texture meter (Stable Micro Systems, England) using three-point bend rig (HDP/3PB) under the following conditions: $1 \mathrm{~mm} / \mathrm{s}$ pre-test speed; $3 \mathrm{~mm} / \mathrm{s}$ test speed; of $10 \mathrm{~mm} / \mathrm{s}$ post-test speed; and penetration distance of $5 \mathrm{~mm}$.

\subsubsection{Sensory evaluation}

The consumers' acceptance test of GFB (approved by the UNICAMP-Brazil Ethics Committee, CAAE 79825817.5.0000.5404), using 120 untrained volunteers. Consumers were asked to evaluate the GFB attributes, using a 9-point unstructured hedonic scale ( $1=$ disliked very much and $9=$ liked very much) according to Meilgaard et al. (2000). The consumption intention test was performed using a structured 5 -point scale $(1=$ would not consume and $5=$ would certainly consume). 


\subsubsection{Nutritional characterization of the gluten-free biscuits}

The nutritional characterization of the GFB were performed by theoretical calculations, based on the nutritional information presented on the ingredient labels and according to the formulations presented in Table 1, considering the weight loss between raw and baked biscuits and the final moisture of biscuits.

\subsubsection{Amino Acid profile of control and gluten-free biscuits}

The amino acid profiles and amino acid scoring were determined for both GFB control and GFB selected in the sensory evaluation according to the methodologies presented in Section 2.2.

\subsection{Statistical analysis}

The results were subjected to analysis of variance (ANOVA) using the SISVAR system, version 5.6, at a significance level of 5\%. When significant, the Scott Knott test was used to determine the statistical differences between means ( $\mathrm{p}$ value $<0.05)$.

\section{Results and Discussion}

\subsection{Characterization of the ingredients}

\subsubsection{Physicochemical characterization}

As shown in Table 2, the water activity of starchy products was lower than 0.60 and of CCL were 0.98 . For the preparation of GFB, CCL moisture content was used to adjust the amount of water to be added to each formulation.

Table 2. Moisture, water activity (Aw), color parameters, and free cyanide contents of cassava derivatives and rice flour used in the manufacture of gluten-free biscuits ${ }^{\mathrm{a}}$.

\begin{tabular}{|c|c|c|c|c|c|c|}
\hline \multirow{2}{*}{ Ingredients $^{\mathbf{b}}$} & \multirow{2}{*}{ Moisture (\%) } & \multirow{2}{*}{ Aw $25^{\circ} \mathrm{C}$} & \multicolumn{3}{|c|}{ Color parameters } & \multirow{2}{*}{$\begin{array}{l}\text { Free cyanide } \\
(\mathrm{mg} \mathrm{HCN} / \mathrm{kg})\end{array}$} \\
\hline & & & $\mathbf{L}^{*}$ & $\mathbf{a}^{*}$ & $\mathbf{b}^{*}$ & \\
\hline $\mathrm{CCL}$ & $89.66 \pm 0.22$ & $0.98 \pm 0$ & $22.05 \pm 1.16$ & $4.95 \pm 0.16$ & $19.15 \pm 2.12$ & 10.91 \\
\hline \multicolumn{7}{|c|}{ Starchy ingredients } \\
\hline WCF & $8.17 \pm 0.06^{\mathrm{b}}$ & $0.42 \pm 0.01^{\mathrm{b}}$ & $83.79 \pm 0.42^{\mathrm{c}}$ & $1.68 \pm 0.15^{\mathrm{b}}$ & $21.60 \pm 0.42^{\mathrm{a}}$ & 17.10 \\
\hline $\mathrm{TF}$ & $3.80 \pm 1.42^{\mathrm{c}}$ & $0.40 \pm 0.01^{\mathrm{c}}$ & $86.28 \pm 0.81^{\mathrm{b}}$ & $1.65 \pm 0.02^{\mathrm{b}}$ & $6.48 \pm 0.57^{c}$ & $<10.00$ \\
\hline $\mathrm{C}$ & $4.80 \pm 0.08^{c}$ & $0.35 \pm 0.02^{\mathrm{d}}$ & $83.90 \pm 0.34^{c}$ & $3.94 \pm 0.13^{\mathrm{a}}$ & $13.54 \pm 0.01^{\mathrm{b}}$ & $<5.00$ \\
\hline $\mathrm{RF}$ & $13.27 \pm 3.22^{\mathrm{a}}$ & $0.60 \pm 0.01^{\mathrm{a}}$ & $98.07 \pm 0.09^{\mathrm{a}}$ & $0.03 \pm 0.04^{\mathrm{c}}$ & $6.47 \pm 0.03^{\mathrm{c}}$ & n.d. \\
\hline
\end{tabular}

${ }^{a}$ Values expressed as mean \pm standard deviation; Different lowercase letters in the column differ from each other by the Scott-Knott test (p-value < $0.05)$; n.d. = not determined. ${ }^{\mathrm{b}} \mathrm{CCL}=$ cooked cassava leaves; $\mathrm{WCF}=$ white cassava flour; $\mathrm{TF}=$ tapioca flour; $\mathrm{C}=$ cuí; $\mathrm{RF}=$ rice flour. $\mathrm{Source}:$ Authors.

According to results presented in Table 2 and Figure 1, the CCL was dark green tending to brown, and according to Butz et al. (2002), this color may indicate that chlorophyll depredated during the cooking process. WCF and cuí were cream color and darker when compared to TF and RF. The WCF was considered more yellowish (higher $\mathrm{b}^{*}$ ), probably due to the presence of other nutrients rather than starch, such as proteins, lipids, and fibers, and was subjected to roasting at temperatures ranging between 90 and $150^{\circ} \mathrm{C}$ (Neves et al., 2017). Tapioca flour, which was opaque white, was considered whiter and lighter 
when compared to cuí (cream color).

Figure 1. Images of cassava derivatives and rice flour, considering (A) visual color and (B) color parameters ( $L^{*}, a^{*}$, and $\left.b^{*}\right)$. Where: $\mathrm{CCL}=$ cooked cassava leaves; $\mathrm{WCF}=$ white cassava flour; $\mathrm{TF}=$ tapioca flour; $\mathrm{C}=$ cuí; $\mathrm{RF}=$ rice flour.
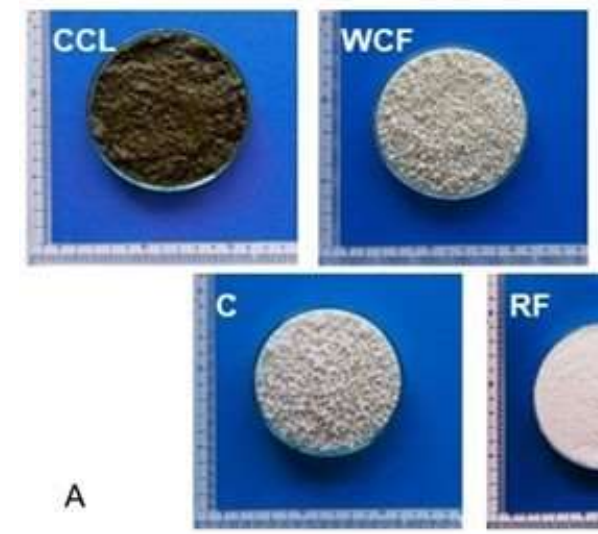

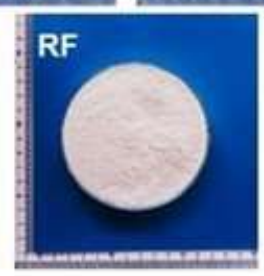

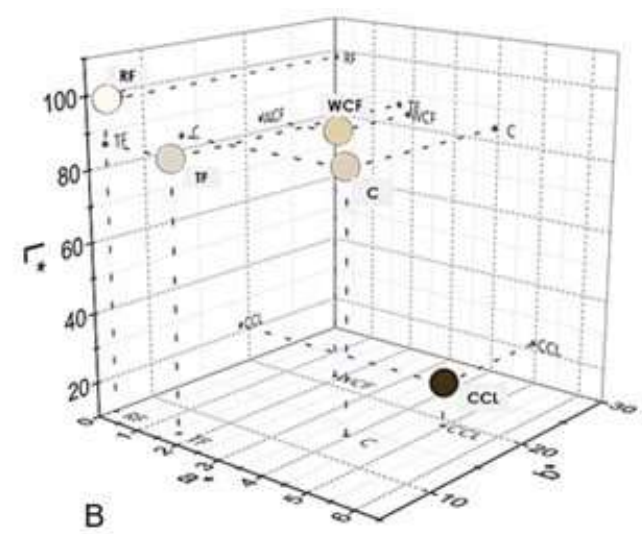

Source: Authors.

\subsubsection{Cyanogenic compounds}

The cyanogenic compounds (Table 2) of CCL, TF and cuí were lower than $11 \mathrm{mg} \mathrm{HCN} / \mathrm{kg}$, while CCL and WCF presented levels lower than $20 \mathrm{mg} \mathrm{HCN} / \mathrm{kg}$ with levels lower than those that could cause intoxication, as the World Health Organization stipulated, the lethal dose for ingesting cyanogenic compounds is $10 \mathrm{mg} / \mathrm{kg}$ of weight (Chisté et al., 2010). According to Cereda and Vilpoux (2013), the combination of the pressing and roasting steps of crushed cassava in the manufacture of flour leads to partial elimination of these compounds, as well as the cooking or drying of cassava leaves, which was also reported by Modesto Junior et al. (2019), Wobeto et al. (2004) and Ngudi et al. (2003).

\subsubsection{Pasting properties}

As can be seen in the pasting properties in Figure 2, rice flour showed higher viscosity and tendency to retrogradation (6892 cP) when compared to cassava flour $(3058 \mathrm{cP})$. Due to the absence of the gluten network, gelatinization of the starch present in the ingredients is necessary to structure the biscuits during baking, as reported by Mancebo et al. (2015) and Witczak et al. (2016). An increase in viscosity of WCF was observed during heating ( $\mu \max =3392 \mathrm{cP}$ and $\mu \mathrm{f}=4868 \mathrm{cP}$ ), thus it has the potential to be used as a structural basis for the preparation of GFB together with rice flour. 
Figure 2. Pasting properties of the starchy ingredients. $\mathrm{RF}=$ rice flour; $\mathrm{WCF}=$ white cassava flour; $\mathrm{TF}=$ tapioca flour; $\mathrm{C}=$ cuí; $\mathrm{T}=$ temperature.

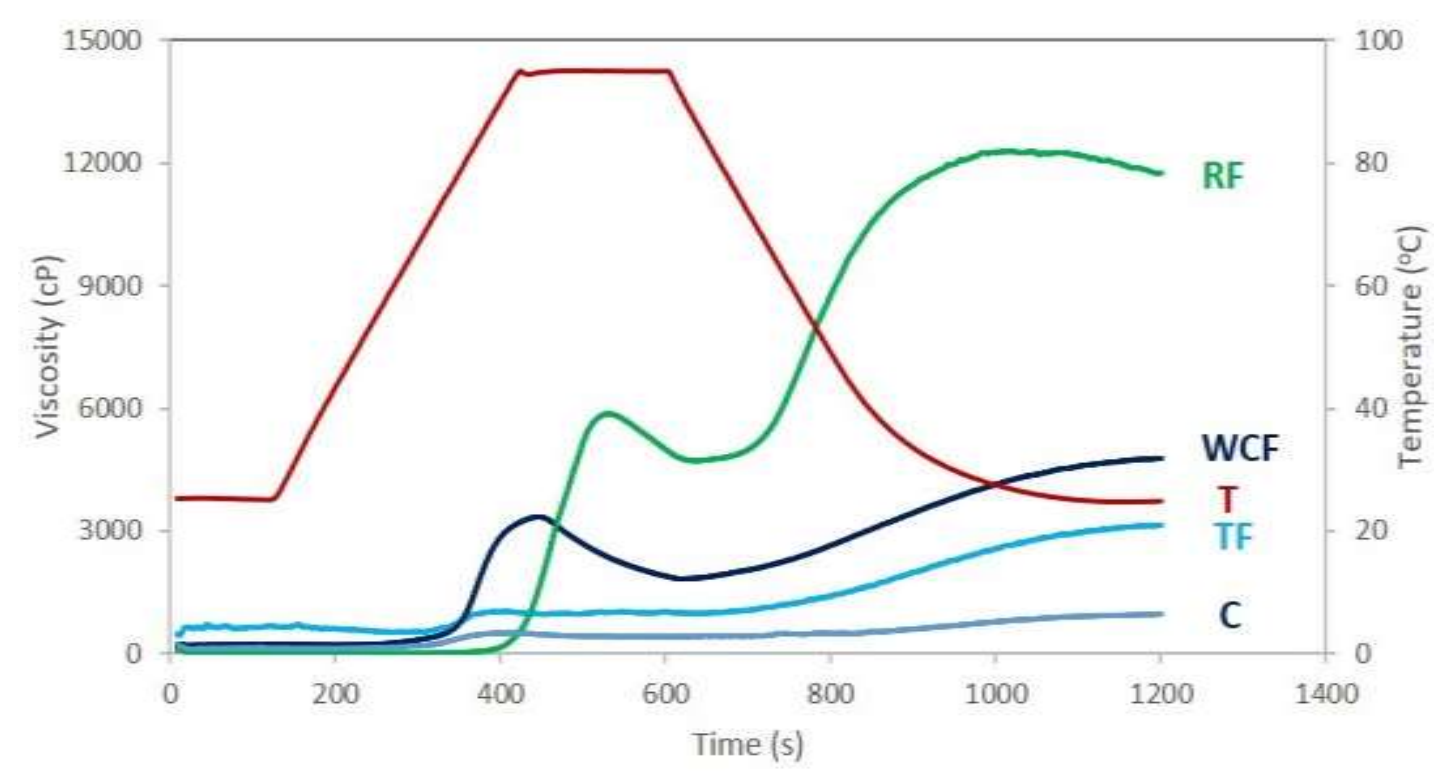

Source: Authors.

The cuí showed an initial viscosity of $196 \mathrm{cP}$ and low final viscosity (1269 cP) (Figure 2), indicating that the product has pregelatinized starch. This behavior enables rapid water absorption during kneading of the GFB, contributing to the formation of the dough. The low retrogradation viscosity (699.62 cP) of starch present in cuí can reduce the hardness of GFB; otherwise, they would become brittle, which is one of the challenges in the manufacture of gluten-free product, especially when using rice flour as a starchy base. The TF presented the lowest viscosity when compared to WCF and RF, probably due to the starch gelatinization during processing with subsequent expansion (Neves et al., 2017).

\subsubsection{Starch morphology}

Despite the heat treatment, cassava root derivatives showed raw starch, what was observed by the birefringence, which demonstrates the presence of the well-defined Maltese cross. It was also observed the presence of raw starch in the rice flour (Figure 3). This result indicates that all starchy ingredients can contribute to the formation of the structure of GFB during kneading, but mainly during baking due to starch gelatinization, as reported by Witczak et al. (2016).

Figure 3. Light polarized light microscopy of (A) white cassava flour; (B) tapioca flour; (C) cuí; (D) rice flour.
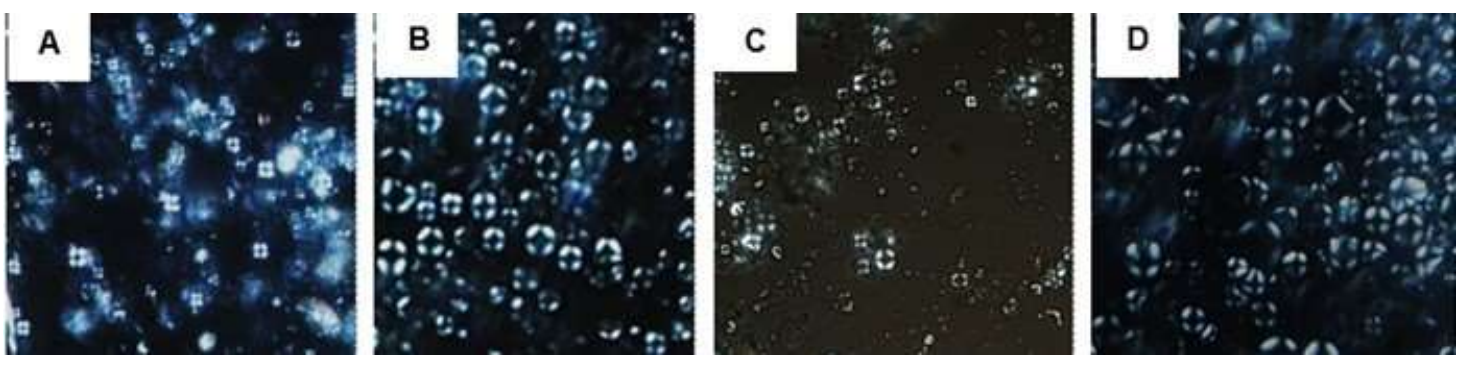

Source: Authors. 


\subsection{Characterization of GFB made with cooked cassava leaves}

\subsubsection{Moisture, water activity, and hardness}

All GFB presented moisture and water activity (Table 3) lower than $4 \%$ and 0.4 , respectively. The F0 exhibited higher moisture content and water activity when compared to the other biscuits. The F1 and F3 showed the lowest hardness while the F2 exhibited the highest hardness values, with no differences between moisture and water activity levels. GFBs with CCl showed hardnesses greater than those observed by Duta and Culetu (2015) (18.33 to $29.35 \mathrm{~N}$ ), who studied GFBs made with oatmeal, while they were similar or superior to the GFB with rice flour and chocolate studied by da Silva and Conti-Silva (2018), which presented values between 31.8 to $49.2 \mathrm{~N}$, indicating that compared to the two authors the use of mixed rice and cassava flour contributed to the increase in the hardness of the biscuits.

\subsubsection{Color measurements}

All GFB of the present study were brown, as shown in Figure 4, probably due to the addition of chocolate to the formulations, as also reported by da Silva and Conti-Silva (2018) for GFB made with the addition of chocolate and inulin. According to Manley (2011), color changes in biscuits can also occur due to the Maillard reactions, starch dextrinization, and caramelization of sugars during baking.

Table 3. Physicochemical parameters, acceptance scores, and consumption intent of GFB made with baked cassava leaves ${ }^{\mathrm{a}, \mathrm{b}}$.

\begin{tabular}{|c|c|c|c|c|}
\hline Parameters & F0 & $\mathrm{F} 1$ & $\mathrm{~F} 2$ & F3 \\
\hline Moisture (\%) & $3.85 \pm 0.61^{\mathrm{a}}$ & $2.64 \pm 0.66^{\mathrm{b}}$ & $2.82 \pm 0.04^{\mathrm{b}}$ & $2.50 \pm 0.04^{\mathrm{b}}$ \\
\hline Water activity & $0.31 \pm 0.01^{\mathrm{a}}$ & $0.28 \pm 0.01^{\mathrm{b}}$ & $0.28 \pm 0.01^{\mathrm{b}}$ & $0.27 \pm 0.01^{\mathrm{b}}$ \\
\hline Hardness $(\mathrm{N})$ & $52.23 \pm 2.02^{\mathrm{b}}$ & $45.04 \pm 5.46^{\mathrm{c}}$ & $58.84 \pm 6.26^{\mathrm{a}}$ & $46.99 \pm 3.8^{c}$ \\
\hline \multicolumn{5}{|l|}{ Color parameters } \\
\hline $\mathrm{L}^{*}$ & $31.99 \pm 0.04^{\mathrm{a}}$ & $29.62 \pm 0.18^{c}$ & $30.16 \pm 0.36^{\mathrm{b}}$ & $29.18 \pm 0.36^{\mathrm{c}}$ \\
\hline$a^{*}$ & $10.85 \pm 0.22^{\mathrm{a}}$ & $9.02 \pm 0.10^{\mathrm{b}}$ & $8.62 \pm 0.13^{c}$ & $8.24 \pm 0.07^{\mathrm{d}}$ \\
\hline$b^{*}$ & $14.05 \pm 0.11^{\mathrm{a}}$ & $12.70 \pm 0.30^{\mathrm{c}}$ & $13.21 \pm 0.17^{\mathrm{b}}$ & $12.48 \pm 0.32^{\mathrm{c}}$ \\
\hline$\Delta \mathrm{E}^{*}($ collor difference $)$ & 0.00 & 3.28 & 3.00 & 4.14 \\
\hline \multicolumn{5}{|l|}{ Acceptance test ${ }^{\mathrm{c}}$} \\
\hline Appearance & $7.11 \pm 1.37^{\mathrm{ns}}$ & $6.92 \pm 1.49^{\mathrm{ns}}$ & $6.99 \pm 1.35^{\mathrm{ns}}$ & $6.76 \pm 1.56^{\mathrm{ns}}$ \\
\hline Color & $7.29 \pm 1.41^{\mathrm{ns}}$ & $7.27 \pm 1.39^{\mathrm{ns}}$ & $7.34 \pm 1.34^{\mathrm{ns}}$ & $7.19 \pm 1.38^{\mathrm{ns}}$ \\
\hline Aroma & $6.11 \pm 1.62^{\mathrm{ns}}$ & $6.39 \pm 1.57^{\mathrm{ns}}$ & $6.31 \pm 1.58^{\mathrm{ns}}$ & $6.28 \pm 1.5^{\mathrm{ns}}$ \\
\hline Crispness & $7.56 \pm 1.46^{\mathrm{a}}$ & $6.93 \pm 1.88^{\mathrm{b}}$ & $7.46 \pm 1.48^{\mathrm{a}}$ & $7.52 \pm 1.4^{\mathrm{a}}$ \\
\hline Flavor & $6.69 \pm 1.82^{\mathrm{ns}}$ & $6.56 \pm 1.71^{\mathrm{ns}}$ & $6.77 \pm 1.63^{\mathrm{ns}}$ & $6.76 \pm 1.47^{\text {ns }}$ \\
\hline Overall acceptance & $7.00 \pm 1.45^{\mathrm{ns}}$ & $6.60 \pm 1.45^{\mathrm{ns}}$ & $6.93 \pm 1.37^{\mathrm{ns}}$ & $6.94 \pm 1.25^{\mathrm{ns}}$ \\
\hline Consumption intent ${ }^{\mathrm{d}}$ & $3.77 \pm 1.01^{\mathrm{ns}}$ & $3.44 \pm 1.02^{\mathrm{ns}}$ & $3.64 \pm 0.98^{\mathrm{ns}}$ & $3.61 \pm 0.89^{\mathrm{ns}}$ \\
\hline
\end{tabular}

${ }^{a}$ Values expressed as mean \pm standard deviation. Different lowercase letters on the same line differ from each other by the Scott-Knott test (P $<0.05)$. ns = not significant. Biscuits F0 = 0\% CCL; F1 = 3.69\% CCL; F2 $=5.54 \%$ CCL; F3 $=7.38 \%$ CCL ${ }^{c}$ Acceptance test $=9$ (liked very much) and 1 (disliked very much). ${ }^{\mathrm{d} C o n s u m p t i o n ~ i n t e n t ~}=5$ (would certainly consume) and 1 (would not consume). Source: Authors. 
Figure 4. Color parameters $\left(\mathrm{L}^{*}, \mathrm{a}^{*}\right.$, and $\left.\mathrm{b}^{*}\right)$ according to the CIELab system of the biscuits (A) and images of the control (F0) and the biscuits made with $7.58 \%$ cassava leaves (F3) (B).
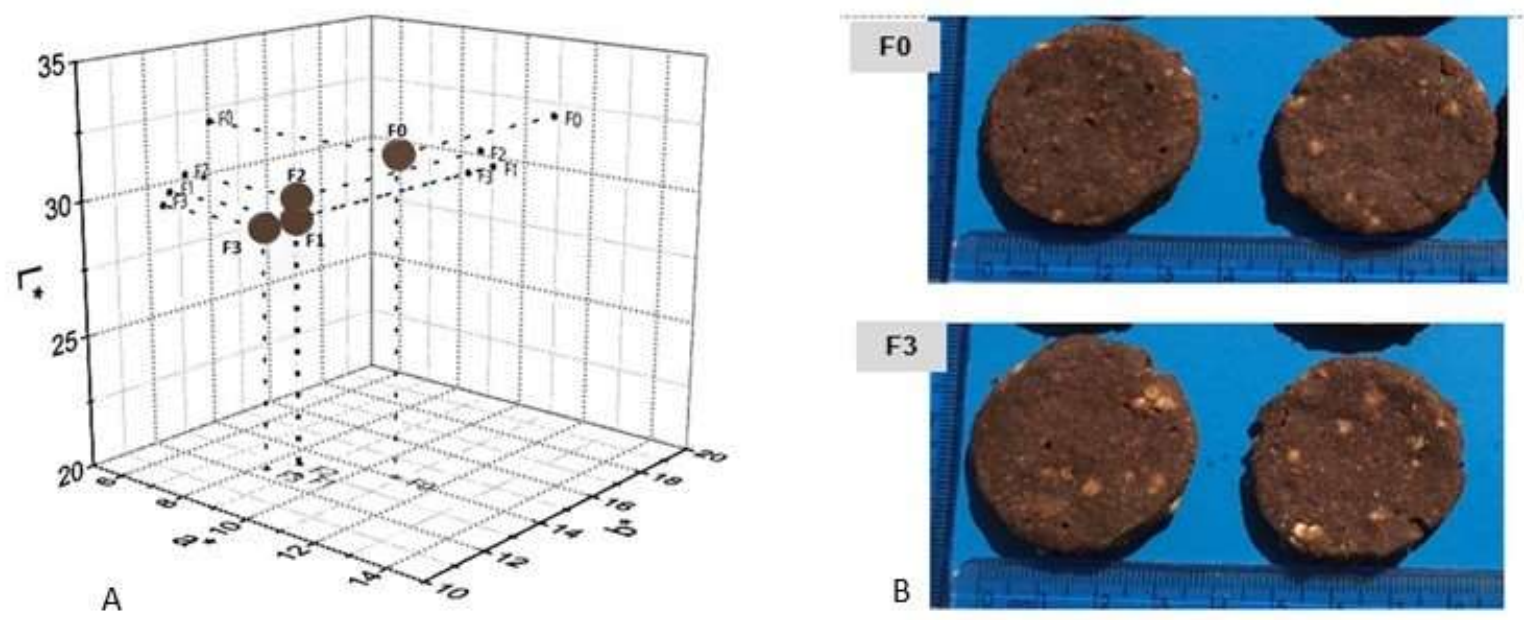

Source: Authors.

The GFB were darker when compared to the control (M0) probably due to the addition of cassava leaves with a dark olive-green color tending to brown (Figure 1 and Table 2), with higher $\mathrm{a}^{*}$ and $\mathrm{b} *$ values (Figure 4), which may have contributed to significant differences in the color parameters $\mathrm{L}^{*}, \mathrm{a}^{*}$, and $\mathrm{b}^{*}$ (Table 3 ) between the biscuits.

\subsubsection{Sensory evaluation}

According to the results in Table 3 and Figure 5, all GFB obtained scores higher than 6 in the acceptance test for all attributes. The addition of cassava leaves did not affect the acceptance as well as the consumption intent of the biscuits. The difference in color (Table 3) did not affect the acceptance of the GFB. A significant difference was observed only for the parameter crispness, and F1and F3 were the least accepted among all formulations. As shown in Figure 5, the overall acceptance scores of GFB ranged from 5 (not liked nor disliked) to 8 (liked moderately), while the attribute crispness scored from 4 (disliked slightly) to 9 (liked very much).

The mean scores (Table 3) obtained in the acceptance test of GFB made with cassava leaves were higher than those reported by Mauro et al. (2010), who found scores of 6.53 and 6.22, and 7.07 and 6.61 for the attributes flavor and consistency of biscuits made with kale-stalk flour and spinach stalk, respectively. Rodrigues et al. (2011) evaluated the overall appearance, flavor, and texture of GFB made with cassava starch and bran and egg as a protein source and found values ranging from 6 (liked slightly) to 7 (liked moderately). According to the results of the characterization of the GFB, they presented good sensory acceptance for all attributes evaluated, regardless of the concentration of cassava leaves. Therefore, these results indicated that cassava derivatives, with emphasis on cassava leaves, associated with rice flour, have the potential for the production of glutenfree products. 
Figure 5. Distribution of assessors for the sensory acceptance of CCL gluten-free biscuits for (A) crispness and (B) overall acceptance. Where $\mathrm{F} 0=$ biscuit with $0 \%$ cooked cassava leaves; $\mathrm{F} 1=$ biscuit with $3.69 \%$ cooked cassava leaves; $\mathrm{F} 2=$ biscuit with $5.54 \%$ cooked cassava leaves; $\mathrm{F} 3=$ biscuit with $7.38 \%$ cooked cassava leaves.

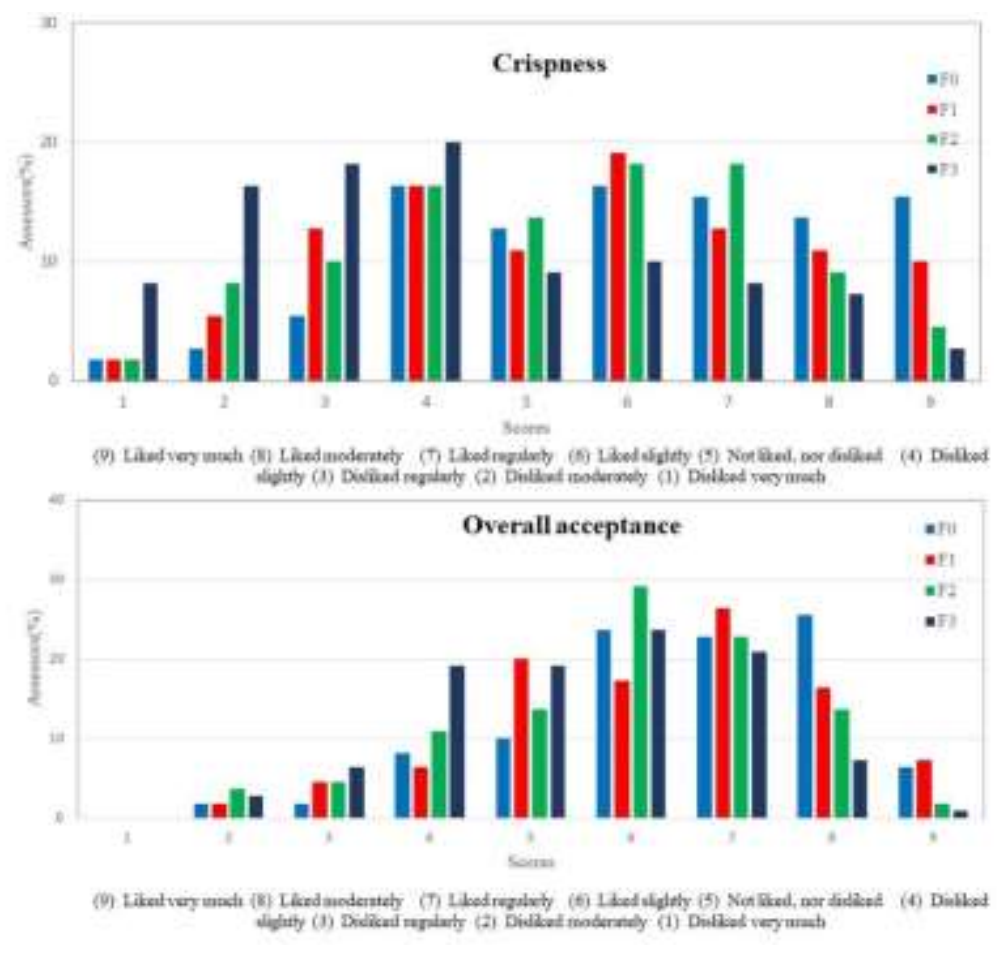

Source: Authors.

\subsection{Nutritional information and amino acids profile of cassava leaves and gluten-free biscuits}

The increased addition of cooked cassava leaves (CCL), which contained $2.75 \%$ protein, led to an increase in protein and fiber levels of the GFB when compared to F0 (Table 4). When comparing F3 with F0 (controls), the protein and fiber increases were $13.46 \%$ and $12.25 \%$, respectively.

Whereas no differences were observed in the acceptance and consumption intent tests (Table 3), the F3 were selected for the analysis of amino acid profile, once they were made with the highest concentration of cooked cassava leaves $(7.38 \%)$ thus presenting the highest protein levels (Table 4).

Table 4. Nutritional information of cooked cassava leaves and gluten-free biscuits ${ }^{\mathrm{a}}$.

\begin{tabular}{lccccc}
\hline \multicolumn{1}{c}{ Values for 100g } & CCL & F0 & F1 & F2 & F3 \\
\hline Energy value (kcal/100g) & 30.60 & 498 & 498 & 504 & 504 \\
Carbohydrates (g) & 4.70 & 63.98 & 64.78 & 64.01 & 64.1 \\
Proteins (g) & 2.75 & 2.12 & 2.14 & 2.39 & 2.45 \\
Total fat (g) & 1.20 & 25.96 & 26.29 & 26.33 & 26.38 \\
Fiber (g) & 1.32 & 4.0 & 4.05 & 4.39 & 4.49 \\
Sodium(mg) & n.d. & 90 & 90 & 80 & 80 \\
\hline
\end{tabular}

${ }^{\mathrm{a} C C L}=$ cooked cassava leaves; F0 = biscuit with 0\% CCL; F1 = biscuit with 3.69\% CCL; F2 = biscuit with 5.54\% CCL; F3 = biscuit with $7.38 \%$ CCL. n.d. = not determined. Source: Authors.

According to the results in Table 5, the essential amino acids present in CCL were 43.64\% of the total, and leucine, phenylalanine, and valine stood out with the higher ratios. Scores lower than 1 determine the limiting amino acids (FAO/WHO, 
1985). When compared to the FAO/WHO (1985), tryptophan was the amino acids limiting (score <1).

The nonessential amino acids present in the highest concentration in the cooked cassava leaves were glutamic acid and aspartic acid, followed by alanine and arginine, while taurine were below the limit of quantification. Ngudi et al. (2003) found higher levels of the same essential amino acids in boiled leaves of different cassava varieties and stated that the variety and intensity of cooking may cause a reduction of these compounds in the leaves. For the 19 amino acids investigated in F0 and F3, only cystine and taurine were below the limit of quantification, while tryptophan was not detected in the formulation F3. Concerning the formulations F0 and F3, the essential amino acids corresponded to $40 \%$ and $36.55 \%$ of the total, respectively. The limiting amino acids (score < 1) for F0 were cystine + methionine for F0 and for F3 were phenylalanine + tyrosine for F3.

Table 5. Amino acid profile of cooked cassava leaves (CCL), control (F0), and F3 biscuits ${ }^{\mathrm{a}}$.

\begin{tabular}{|c|c|c|c|c|c|c|c|c|c|c|}
\hline \multirow[b]{2}{*}{ Amino acids ${ }^{b}$} & \multicolumn{3}{|c|}{ CCL } & \multicolumn{3}{|c|}{ F0 } & \multicolumn{3}{|c|}{ F3 } & \multirow[b]{2}{*}{$\begin{array}{l}\text { Score } \\
\text { FAO }^{d}\end{array}$} \\
\hline & $\begin{array}{c}\text { mg/g } \\
\text { sample }\end{array}$ & $\begin{array}{c}\mathrm{mg} / \mathrm{g} \\
\text { protein }\end{array}$ & $\mathbf{S} \mathbf{A} \mathbf{A}^{d}$ & $\begin{array}{c}\text { mg/g } \\
\text { sample }\end{array}$ & $\begin{array}{c}\mathrm{mg} / \mathrm{g} \\
\text { protein }\end{array}$ & $\mathbf{S} \mathbf{A} \mathbf{A}^{d}$ & $\begin{array}{c}\text { mg/g } \\
\text { sample }\end{array}$ & $\begin{array}{c}\mathrm{mg} / \mathrm{g} \\
\text { protein }\end{array}$ & $\mathbf{S} \mathbf{A A}{ }^{c}$ & \\
\hline \multicolumn{11}{|c|}{ Essential amino acids (EAA) } \\
\hline VAL & 0.16 & 65.35 & 3.63 & 0.80 & 57.55 & 3.20 & 0.90 & 62.50 & 2.31 & 18.00 \\
\hline TER & 0.12 & 47.22 & 3.63 & 0.50 & 35.97 & 2.77 & 0.60 & 41.67 & 1.07 & 13.00 \\
\hline MET & 0.05 & 18.13 & & 0.20 & 14.39 & & 0.20 & 13.89 & & \\
\hline HIS & 0.06 & 25.30 & & 0.30 & 21.58 & & 0.30 & 20.83 & & 0.00 \\
\hline ILE & 0.14 & 56.49 & 3.14 & 0.50 & 35.97 & 2.00 & 0.60 & 41.67 & 4.63 & 18.00 \\
\hline LEU & 0.27 & 106.2 & 4.25 & 1.00 & 71.94 & 2.88 & 1.20 & 83.33 & 2.50 & 25.00 \\
\hline PHE & 0.17 & 69.56 & & 0.70 & 50.36 & & 0.90 & 62.50 & & \\
\hline TRP & 0.01 & 5.48 & 0.84 & 1.10 & 79.14 & 12.17 & n.q. & n.q. & n.q. & 6.50 \\
\hline LYS & 0.15 & 58.60 & 2.66 & 0.50 & 35.97 & 1.64 & 0.60 & 41.67 & 16.73 & 22.00 \\
\hline Total EAA & 1.13 & 65.28 & & 5.60 & 402.88 & & 5.30 & 368.06 & 3.89 & 18.00 \\
\hline PHE+TYR & 0.20 & 81.79 & 3.27 & 1.10 & 79.14 & 3.17 & 1.40 & 97.22 & 0.58 & 25.00 \\
\hline CYS+MET & 0.08 & 29.09 & 1.21 & 0.20 & 14.39 & 0.60 & 0.20 & 13.89 & 2.31 & 24.00 \\
\hline \multicolumn{11}{|c|}{ Conditionally essential amino acids (CEAA) } \\
\hline $\mathrm{ARG}$ & 0.17 & 67.03 & & 0.90 & 64.75 & & 1.00 & 69.44 & & \\
\hline GLY & 0.16 & 63.24 & & 0.60 & 43.17 & & 0.70 & 48.61 & & \\
\hline CYS & 0.03 & 10.96 & & n.q. & n.q. & & n.q. & n.q. & & \\
\hline PRO & 0.13 & 53.96 & & 0.70 & 50.36 & & 0.80 & 55.56 & & \\
\hline TYR & 0.03 & 12.23 & & 0.40 & 28.78 & & 0.50 & 34.72 & & \\
\hline Total CEAA & 0.52 & 207.4 & & 2.60 & 187.05 & & 3.00 & 208.33 & & \\
\hline \multicolumn{11}{|c|}{ Nonessential amino acids (NEAA) } \\
\hline ALA & 0.18 & 72.51 & & 0.70 & 50.36 & & 0.90 & 62.50 & & \\
\hline ASP & 0.24 & 94.86 & & 1.50 & 107.91 & & 1.50 & 107.91 & & \\
\hline GLU & 0.31 & 124.7 & & 2.80 & 201.44 & & 3.00 & 208.33 & & \\
\hline SER & 0.12 & 48.06 & & 0.70 & 50.36 & & 0.70 & 48.61 & & \\
\hline TAU & n.q. & n.q. & & n.q. & n.q. & & n.q. & n.q. & & \\
\hline Total NEAA & 0.85 & 65.28 & & 5.70 & 410.07 & & 6.10 & 423.61 & & \\
\hline Total AA & 2.50 & 1000 & & 13.90 & 1000 & & 14.40 & 1000 & & \\
\hline
\end{tabular}




\section{Conclusion}

Cassava leaves and the mixture of starchy ingredients, such as cassava flour and cuí, used in GFB formulations, contributed to the production of gluten-free products for celiac. The sensory acceptance and the consumption intention scores were greater than 6 and 3, corresponding to "liked slightly" and "would consume, would not consume", respectively, which indicates that it is possible to increase the added value of CCL in bakery products. In addition, the increase in cassava leaves consumption can also be an alternative for family farming, thus respecting the concept of regionalization, contributing to a healthy diet and taking into account the defense of species biodiversity and population habits, especially in developing countries.

\section{Acknowledgments}

The authors thank the Coordenação de Aperfeiçoamento de Pessoal de Nível Superior-Brazil (CAPES) - Finance Code 001; CNPq for the Ph.D. scholarship and bench fee for Elisa Cristina Andrade Neves; PIBIC/AE-UNICAMP for the scholarship of Beatriz Andrade Moyses.

\section{References}

AOAC. (2005). Official Methods of Analysis (15th ed.). Association of Official Analytical Chemists.

Butz, P., Edenharder, R., García, A. F., Fister, H., Merkel, C., \& Tauscher, B. (2002). Changes in functional properties of vegetables induced by high pressure treatment. Food Research International, 35(2-3), 295-300. https://doi.org/10.1016/S0963-9969(01)00199-5

Cereda, M. P., \& Vilpoux, O. F. (2013). Tecnologias, usos e potencialidades de tuberosas amiláceas latino americanas (3rd ed.). Fundação Cargill.

Chisté, R. C., Cohen, K. de O., Mathias, E. de A., \& Oliveira, S. S. (2010). Quantificação de cianeto total nas etapas de processamento das farinhas de mandioca dos grupos seca e d'água. Acta Amazonica, 40(1), 221-226. https://doi.org/10.1590/S0044-59672010000100028

da Silva, T. F., \& Conti-Silva, A. C. (2018). Potentiality of gluten-free chocolate cookies with added inulin/oligofructose: Chemical, physical and sensory characterization. LWT - Food Science and Technology, 90, 172-179. https://doi.org/10.1016/j.lwt.2017.12.031

Di Cairano, M., Galgano, F., Tolve, R., Caruso, M. C., \& Condelli, N. (2018). Focus on gluten free biscuits: Ingredients and issues. Trends in Food Science \& Technology, 81, 203-212. https://doi.org/10.1016/j.tifs.2018.09.006

Duta, D. E., \& Culetu, A. (2015). Evaluation of rheological, physicochemical, thermal, mechanical and sensory properties of oat-based gluten free cookies. Journal of Food Engineering, 162, 1-8. https://doi.org/10.1016/j.jfoodeng.2015.04.002

FAO/WHO, F. and A. O. of the U. N. and W. H. O. (1985). Energy and protein requirements (pp. 1-8). FAO/WHO.

FAOSTAT, F. and A. O. of the U. N. (2020). Production, crops (pp. 1-5). http://www.fao.org/faostat/en/\#home/

Hagen, S. R., Augustin, J., Grings, E., \& Tassinari, P. (1993). Precolumn phenylisothiocyanate derivatization and liquid chromatography of free amino acids in biological samples. Food Chemistry, 46(3), 319-323. https://doi.org/10.1016/0308-8146(93)90127-2

Hobbs, J. E. (2020). Food supply chains during the COVID-19 pandemic. Canadian Journal of Agricultural Economics, 68(2), 171-176. https://doi.org/10.1111/cjag.12237

Hoover, E. (2020). Native food systems impacted by COVID. Agriculture and Human Values. https://doi.org/10.1007/s10460-020-10089-7

Laborde, D., Martin, W., Swinnen, J., \& Vos, R. (2020). COVID-19 risks to global food security. Science, 369(6503), 500-502. https://doi.org/10.1126/science.abc4765

Latif, S., \& Müller, J. (2015). Potential of cassava leaves in human nutrition: A review. Trends in Food Science \& Technology, 44(2), 147-158. https://doi.org/10.1016/j.tifs.2015.04.006

Lucas, B., \& Sotelo, A. (1980). Effect of different alkalies, temperature, and hydrolysis times on tryptophan determination of pure proteins and of foods. Analytical Biochemistry, 109(1), 192-197. https://doi.org/10.1016/0003-2697(80)90028-7

Mancebo, C. M., Picón, J., \& Gómez, M. (2015). Effect of flour properties on the quality characteristics of gluten free sugar-snap cookies. LWT - Food Science and Technology, 64(1), 264-269. https://doi.org/10.1016/j.lwt.2015.05.057

Manley, D. (2011). Manley's technology of biscuits, crackers and cookie (4th Ed.). Woodhead Publishing Limited.

Meilgaard, M., Civille, G. V., \& Carr, B. T. (2000). Sensory Evaluation Techniques (3rd Ed.). CRC Press.

Modesto Junior, E. N., Chisté, R. C., \& Pena, R. da S. (2019). Oven drying and hot water cooking processes decrease HCN contents of cassava leaves. Food Research International, 119, 517-523. https://doi.org/10.1016/j.foodres.2019.01.029 
Research, Society and Development, v. 10, n. 3, e12010313071, 2021

(CC BY 4.0) | ISSN 2525-3409 | DOI: http://dx.doi.org/10.33448/rsd-v10i3.13071

Muggah, E. M., Duizer, L. M., \& McSweeney, M. B. (2016). A comparison of sensory properties of artisanal style and industrially processed gluten free breads. International Journal of Gastronomy and Food Science, 3, 38-46. https://doi.org/10.1016/j.ijgfs.2016.01.001

Neves, E. C. A., Neves, D. A., Lobato, K. B. S., Nascimento, G. C., \& Clerici, M. T. P. S. (2017). Technological aspects of processing off cassava derivatives. In C. Klein (Ed.), Handbook on cassava: production, potential uses and recent advances. 500. Nova Science Publishers.

Ngudi, D. D., Kuo, Y.-H., \& Lambein, F. (2003). Cassava cyanogens and free amino acids in raw and cooked leaves. Food and Chemical Toxicology, 41(8), 1193-1197. https://doi.org/10.1016/S0278-6915(03)00111-X

Rodrigues, J. P. de M., Caliari, M., \& Asquieri, E. R. (2011). Caracterização e análise sensorial de biscoitos de polvilho elaborados com diferentes níveis de farelo de mandioca. Ciência Rural, 41(12), 2196-2202. https://doi.org/10.1590/S0103-84782011001200025

Silva, D. A. Q., Wahanik, A. L., Azeredo, E. M. C., Schmiele, M., Chang, Y. K., \& Clerici, M. T. P. S. (2015). Gluten-free cookie with potato starch and modified albumin: development, technology, nutrition and sensory evaluation. In R. T. Langdon (Ed.), Gluten-Free Diets: Food Sources, Role in Celiac Disease and Health Benefits (pp. 1-25). Nova Science Publishers.

Valitutti, F., Iorfida, D., Anania, C., Trovato, C., Montuori, M., Cucchiara, S., \& Catassi, C. (2017). Cereal Consumption among Subjects with Celiac Disease: A Snapshot for Nutritional Considerations. Nutrients, 9(4), 396. https://doi.org/10.3390/nu9040396

White, J. A., Hart, R. J., \& Fry, J. C. (1986). An evaluation of the Waters Pico-Tag system for the amino-acid analysis of food materials. Journal of Automatic Chemistry, 8(4), 170-177. https://doi.org/10.1155/S1463924686000330

Witczak, M., Ziobro, R., Juszczak, L., \& Korus, J. (2016). Starch and starch derivatives in gluten-free systems - A review. Journal of Cereal Science, 67, 4657. https://doi.org/10.1016/j.jcs.2015.07.007

Wobeto, C., Corrêa, A. D., Abreu, C. M. P. de, \& Santos, C. D. dos. (2004). Cianeto na farinha e folhas de mandioca (Manihot esculenta Crantz). Ciência e Agrotecnologia, 28(5), 1115-1118. https://doi.org/10.1590/S1413-70542004000500020

Y1lmaz, V. A., \& Koca, İ. (2020). Development of gluten-free corn bread enriched with anchovy flour using TOPSIS multi-criteria decision method. International Journal of Gastronomy and Food Science, 22, 100281. https://doi.org/10.1016/j.ijgfs.2020.100281 